\title{
Kinetics and mechanism of interaction of some bioactive ligands with cis-diaqua(cis-1,2-diaminocyclohexane)platinum(II) in aqueous medium
}

\author{
P KARMAKAR, S RAY, S MALLICK, B K BERA, A MANDAL, S MONDAL \\ and A K GHOSH* \\ Department of Chemistry, The University of Burdwan, Burdwan 713 104, India \\ e-mail: alakghosh2002@yahoo.co.in
}

MS received 16 December 2012; revised 25 February 2013; accepted 22 March 2013

\begin{abstract}
The substitution reaction of $c i s-\left[\mathrm{Pt}(\text { cis-dach })\left(\mathrm{H}_{2} \mathrm{O}\right)_{2}\right]^{2+}$ (where 'dach' is cis-1,2-diaminocyclohexane) with 2-thiouracil $(\mathrm{S}, \mathrm{N}), 1,2$-cyclohexanedionedioxime $(\mathrm{N}, \mathrm{N})$ and acetylacetone $(\mathrm{O}, \mathrm{O})$ were studied in aqueous solution in $0.10 \mathrm{M} \mathrm{NaClO}_{4}$ under pseudo-first order conditions as a functions of concentration, $\mathrm{pH}$ and temperature using UV-Vis spectrophotometry. The substitution reaction proceeds via rapid outer sphere association complex formation, followed by two slow consecutive steps. The first of these involves ligand-assisted deaquation, while second involves chelation as the second aqua ligand is displaced. The association equilibrium constant $\left(\mathrm{K}_{\mathrm{E}}\right)$ for the outer sphere complex formation has been evaluated together with rate constants for the two subsequent steps. The rate constants increase with increasing ligand concentration and the evaluated activation parameters for all reactions suggest an associative substitution mechanism for both the aqua ligand substitution processes. The product of the reaction has been characterized by IR, NMR and ESI-MS spectral analysis; which throws more light on the mechanistic behaviour of platinum(II) antitumour complexes.
\end{abstract}

Keywords. Platinum(II); diaminocyclohexane; kinetics; bioactivity.

\section{Introduction}

Cisplatin (CDDP) is one of the most effective anticancer drugs currently used worldwide in the treatment of testicular, ovarian, and other tumours. ${ }^{1,2}$ The usefulness of this transition metal complex is limited, however, by its limited spectrum of responsive tumours, rather severe host toxicities such as nausea and vomiting, nephrotoxicity, neurotoxicity and the potential to induce resistance in otherwise responsive tumour types. ${ }^{3}$ In addition, cisplatin has been classified as a probable human carcinogen. ${ }^{4}$ In the search for cisplatin analogs with a better toxicity profile and an improved spectrum of activity, a large number of platinum $(\mathrm{Pt})$ derivatives have been synthesized and investigated. $^{5-7}$ One of the most promising second generation platinum complexes was cis-dichloro(1,2diaminocyclohexane)platinum(II). ${ }^{8}$ The biological properties of this complex which included excellent antitumour activity, little or no nephrotoxicity and lack of cross resistance with CDDP. ${ }^{8}$ Much progress has been made in elucidating its mode of action, and

*For correspondence many details of the mechanism by which platinumbased drugs kill cancer cells are now well-established. Biological and chemical experiments have indicated that the interaction of cisplatin with DNA is responsible for its antineoplastic activity. ${ }^{9,10}$ Nevertheless, some essential chemical processes, related to what happens before the cisplatin reaches the DNA, generally considered its final target, are still to be identified. Among these processes, the best known is the formation of aqua species, the main reaction of activation of the drug which occurs in the cytoplasmic compartment by hydrolysis of the chloride ligands. However, many other non-genomic biomolecules could be potential targets for platinum. Sulphur-rich biomolecules, including free amino acids (cysteine and methionine), oligopeptides (glutathione), and proteins represent good targets for a soft metal such as $\mathrm{Pt}(\mathrm{II}) .{ }^{11-13}$ Moreover, the need to improve the cisplatin clinical protocol drives much research into better understanding of its antitumour activity mechanism. On the other hand, in order to overcome acquired cellular resistance to cisplatin, much effort is currently devoted to the discovery of new $\mathrm{Pt}$ anticancer drugs.

We reported the kinetics and mechanism of the complex formation reaction of $c i s-\left[\mathrm{Pt}(\text { cis-dach })\left(\mathrm{H}_{2} \mathrm{O}\right)_{2}\right]^{2+}$ 
(where 'dach' is cis-1,2-diaminocyclohexane) with some biologically relevant nitrogen, oxygen and sulphur donor nucleophiles (2-thiouracil, 1,2-cyclohexanedionedioxime and acetylacetone). The aqua complex studied is more reactive than the corresponding chloro complex. The coordinated water molecule on $\mathrm{Pt}(\mathrm{II})$ centre has been shown to be very labile and can more easily be substituted than a stronger nucleophilic group such as chloride. These nucleophiles were investigated because of their different nucleophilicity, steric hindrance, binding properties and biological relevance. This study is of fundamental importance to unravel the mode of action of this class of compounds and it throws more light on the kinetic and mechanistic behaviour of platinum antitumour complexes. The goal is to contribute to the elucidation of the whole mechanism employed by these compounds to reach the biological target.

\section{Experimental}

The substrate chloro complex cis-dichloro-(cisdach)platinum(II) was prepared according to literature method. ${ }^{14}$ The reactant complex cis- $[\mathrm{Pt}($ cisdach $\left.)\left(\mathrm{OH}_{2}\right)_{2}\right]\left(\mathrm{ClO}_{4}\right)_{2}(1)($ dach $=$ diaminocyclohexane $)$ was prepared from cis-dichloro-(cis-dach)platinum(II) by hydrolysis in the presence of two molar equivalent of silver perchlorate. The chloro compound spread over the aqueous solution of silver perchlorate and mixture was kept for $24 \mathrm{~h}$ and then filtered to remove $\mathrm{AgCl}$. The diaqua complex was then characterized spectrophotometrically. The $\mathrm{pHs}$ of the solutions were maintained at $\mathrm{pH}$ (4.0), so that perchlorate salt exists as the diaqua species. The products of the reaction between $(1)$ and 2-thiouracil $\left(\mathrm{L}^{1} \mathrm{H}\right)$ or 1,2-cyclohexanedionedioxime $\left(\mathrm{L}^{2} \mathrm{H}\right)$ or acetylacetone $\left(\mathrm{L}^{3} \mathrm{H}\right)$ were prepared by mixing the reagents at $\mathrm{pH} 4.0$ in different molar ratio: viz 1:1, $1: 2,1: 3,1: 4$ and 1:5 and thermostating the mixture at $60^{\circ} \mathrm{C}$ for $48 \mathrm{~h}$. The absorption spectra of the resulting solutions were recorded and all are found to exhibit almost identical absorbances at 327, 298 and $308 \mathrm{~nm}$ wavelength for $\mathrm{L}^{1} \mathrm{H}, \mathrm{L}^{2} \mathrm{H}$ and $\mathrm{L}^{3} \mathrm{H}$, respectively. The spectral differences between the product complexes and the substrate complex are shown in figure 1 . The relative $\lambda_{\max }$ positions of the LH-substituted products are in accordance with the polarizibility of the ligands.

The compositions of the products in the reaction mixtures were determined by Job's method of continuous variation (figure 2). The metal: ligand ratios were found to be $1: 1$ for $\mathrm{L}^{1} \mathrm{H}, \mathrm{L}^{2} \mathrm{H}$ and $\mathrm{L}^{3} \mathrm{H}$.

Complex (1) and 2-thiouracil $\left(\mathrm{L}^{1} \mathrm{H}\right)$ were mixed in 1:1 molar ratio at $\mathrm{pH} 4.0$ and a yellowish product was isolated. The IR spectrum of the yellowish product in

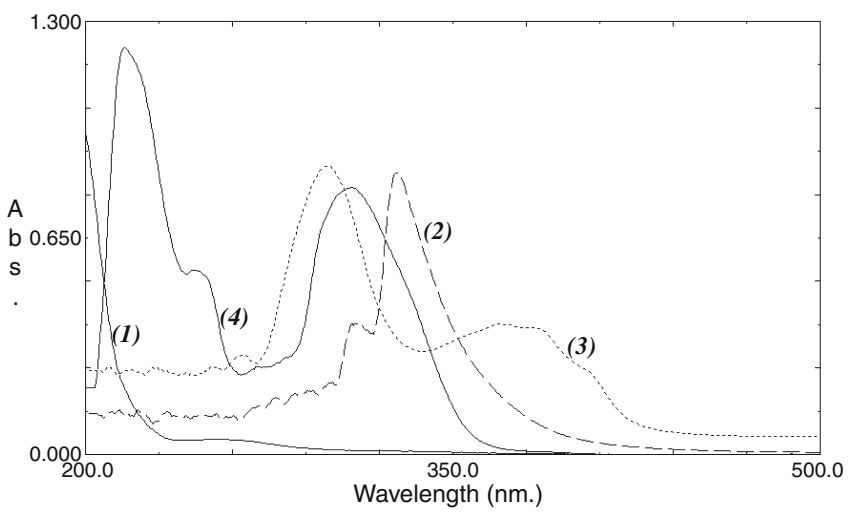

Figure 1. Spectra of the starting complex (1), $\mathrm{L}^{1} \mathrm{H}$ substituted complex (2) $\mathrm{L}^{2} \mathrm{H}$ substituted complex (3) and $\mathrm{L}^{3} \mathrm{H}$ substituted complex (4). [complex (1)] $=2.00 \times 10^{-4} \mathrm{~mol}$ $\mathrm{dm}^{-3},\left[\mathrm{~L}^{1} \mathrm{H}\right],\left[\mathrm{L}^{2} \mathrm{H}\right]$ and $\left[\mathrm{L}^{3} \mathrm{H}\right]=4.00 \times 10^{-3} \mathrm{~mol} \mathrm{dm}^{-3}$, cell used $=1 \mathrm{~cm}$ quartz, $\mathrm{pH}=4.0$, and ionic strength $=0.10 \mathrm{~mol}$ $\mathrm{dm}^{-3} \mathrm{NaClO}_{4}$.

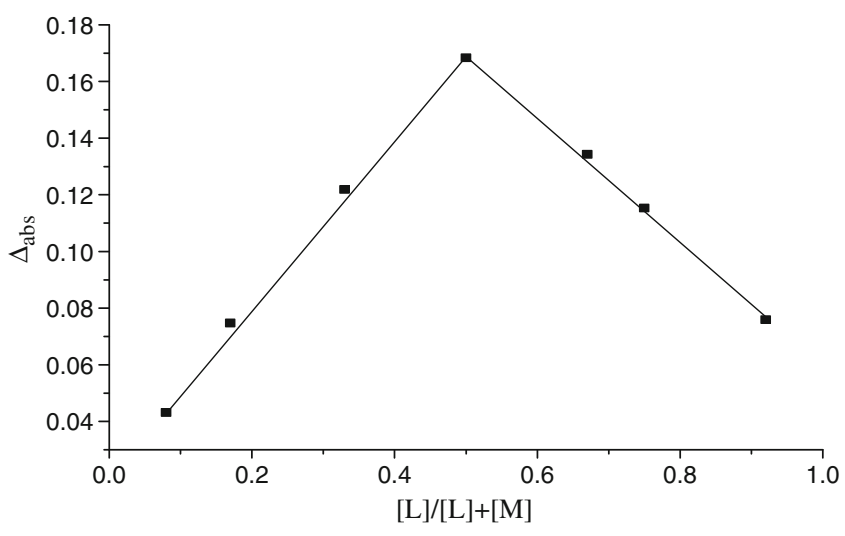

Figure 2. Job's plot for the reaction between complex (1) and $\mathrm{L}^{3} \mathrm{H}$ at $\mathrm{pH}=4.0$ and ionic strength $=0.10 \mathrm{~mol} \mathrm{dm} \mathrm{dm}^{-3}$ $\mathrm{NaClO}_{4}$.

the $\mathrm{KBr}$ disc shows a strong band at 3411 together with medium band at $530 \mathrm{~cm}^{-1}$. The IR spectrum of $\mathrm{L}^{1} \mathrm{H}$ does not show any $v(\mathrm{SH})$ band; hence in the solid state ligand exists mainly in the keto-thione form. The broad bands at 3424 and $3411 \mathrm{~cm}^{-1}$ in $\mathrm{L}^{1} \mathrm{H}$ and its substituted complex, respectively, are due to $v(\mathrm{OH})$ of water molecules and hydrogen bonds of the type $\mathrm{N}-$ $\mathrm{H}$. . O . The $v(\mathrm{NH})$ bands at 3134 and $3049 \mathrm{~cm}^{-1}$ are strongly affected on complexation to $\mathrm{Pt}(\mathrm{II})$; the presence of only one band at $3236 \mathrm{~cm}^{-1}$ indicates $\mathrm{NH}$ group participates in bond formation with metal ion. ${ }^{15}$ The $v(\mathrm{C}=\mathrm{O})$ and $v(\mathrm{C}=\mathrm{N})$ bands of $\mathrm{L}^{1} \mathrm{H}$ at 1702 and $1629 \mathrm{~cm}^{-1}$, respectively, are affected on complexation. With respect to the free $\mathrm{L}^{1} \mathrm{H}$, the band at $1239 \mathrm{~cm}^{-1}$ corresponding to stretching of the most $v(\mathrm{C}=\mathrm{S})$ character shifts to lower wave number in product, which indicate the stronger coordination of the sulphur atom 
to the $\mathrm{Pt}(\mathrm{II})$. The band at $530 \mathrm{~cm}^{-1}$ is also assigned to $v(\mathrm{Pt}-\mathrm{N})$ bond formation. ${ }^{16}$ The spectrum suggests that the final product is an $\left(\mathrm{S}, \mathrm{N}_{3}\right)$ coordinated adjacent chelate and the 2-thiouracil behave as a bidentate ligand in the experimental $\mathrm{pH} .{ }^{17}$ Similarly, the presence of moderately strong band at $636 \mathrm{~cm}^{-1}$ for brown product of complex (1) and $\mathrm{L}^{3} \mathrm{H}$ indicates the formation of $\mathrm{Pt}-\mathrm{O}$ bond. ${ }^{18}$

The aqueous solution of cis-[Pt(cis-dach $\left.)\left(\mathrm{OH}_{2}\right)_{2}\right]^{2+}$ and $\mathrm{L}^{1} \mathrm{H}$ were mixed in a $1: 1$ molar ratio and the mixture was thermostated at $60^{\circ} \mathrm{C}$ for $48 \mathrm{~h}$ and used for ESI-MS measurement. The ESI mass spectrum of the resulting solution is shown in figure 3.

It is clear from this spectrum that the ion at $\mathrm{m} / \mathrm{z}$ 436.20 (minor peak) has become the precursor ion species in the mixture solution and this is tentatively attributed to $\left(\mathrm{L}^{1} \mathrm{H}+\mathrm{Pt}(\mathrm{II})+\text { dach }-\mathrm{H}^{+}\right)^{+}$. The peak at 450.25 indicates the formation of the product $\left(\mathrm{L}^{2} \mathrm{H}+\right.$ $\mathrm{Pt}(\mathrm{II})+$ dach $\left.-\mathrm{H}^{+}\right)^{+}$(figure 4). Similarly, the major peak at 408.3070 assigned to the $\left(\mathrm{L}^{3} \mathrm{H}+\mathrm{Pt}(\mathrm{II})+\right.$ dach

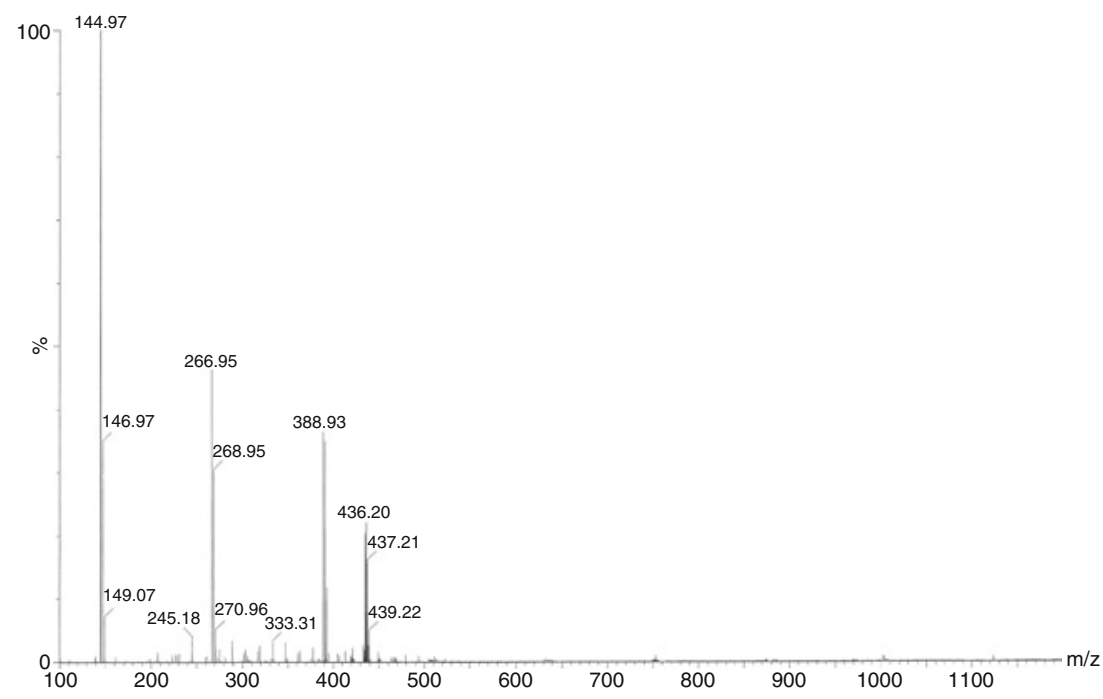

Figure 3. ESI- mass spectrum of the product for complex (1) and $\mathrm{L}^{1} \mathrm{H}$ at $\mathrm{pH} 4.0$ in aqueous medium and at ionic strength $0.1 \mathrm{~mol} \mathrm{dm}^{-3} \mathrm{NaClO}_{4}$.

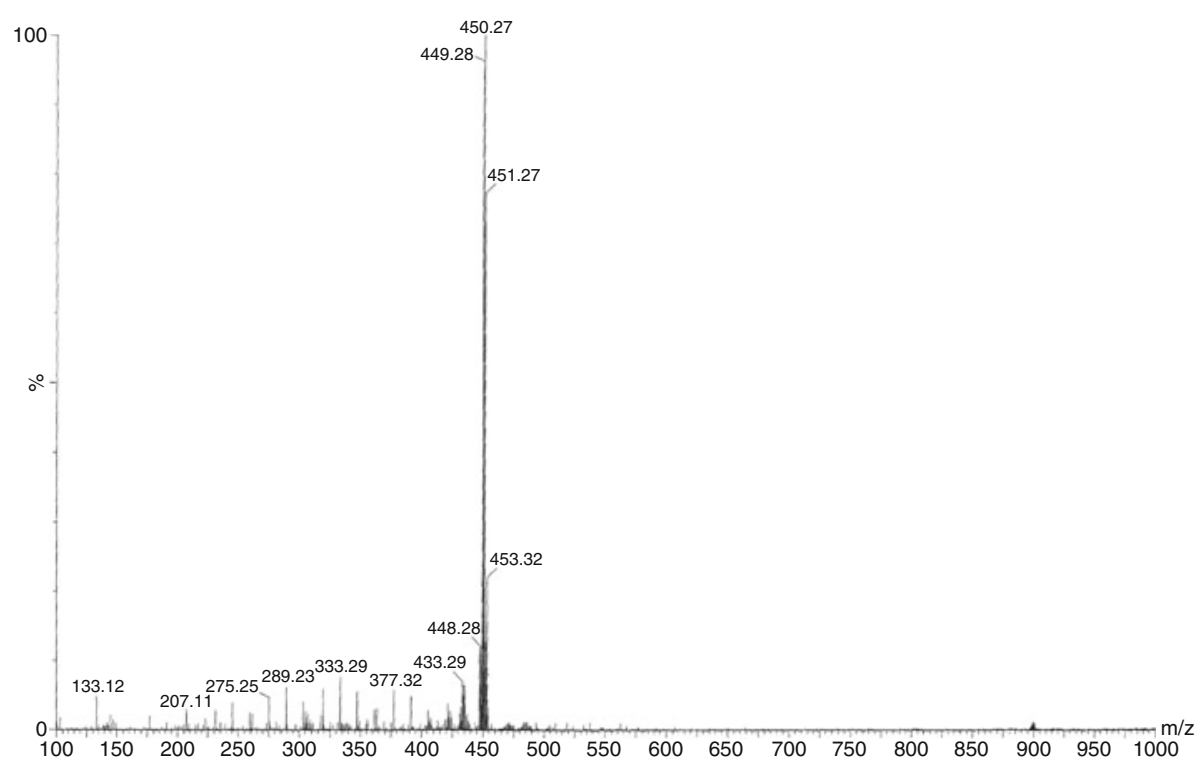

Figure 4. ESI- mass spectrum of the product for complex (1) and $\mathrm{L}^{2} \mathrm{H}$ at $\mathrm{pH} 4.0$ in aqueous medium and at ionic strength $0.1 \mathrm{~mol} \mathrm{dm}^{-3} \mathrm{NaClO}_{4}$. 


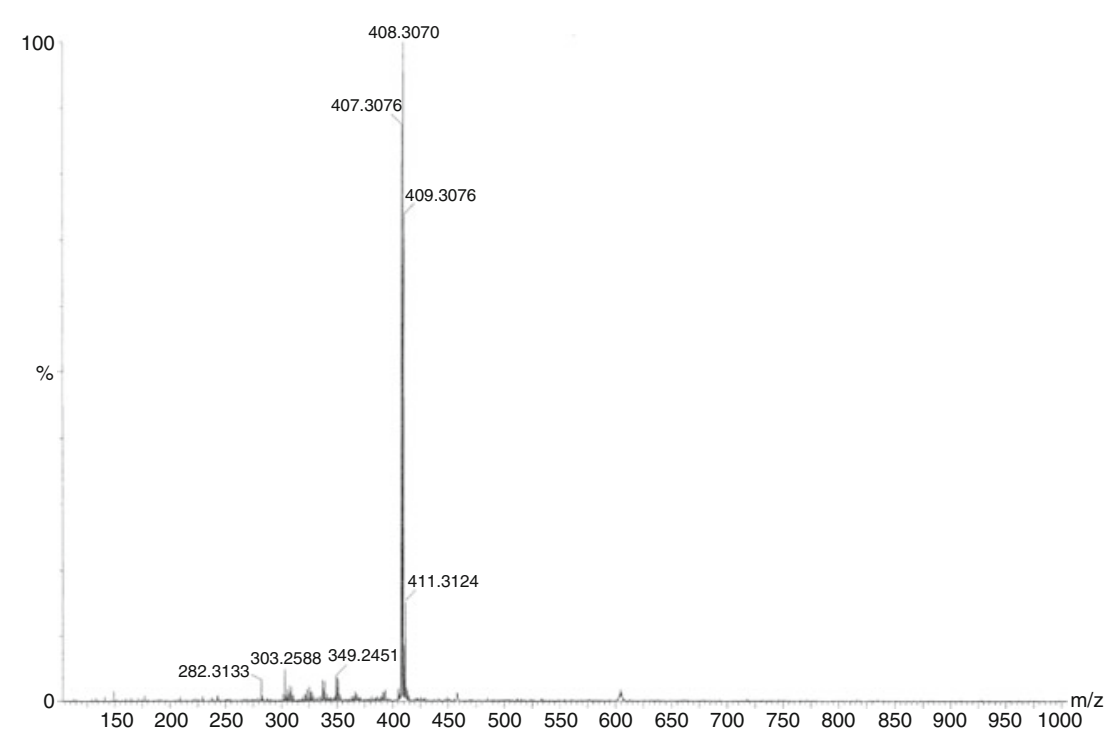

Figure 5. ESI-mass spectrum of the product for complex (1) and $\mathrm{L}^{3} \mathrm{H}$ at $\mathrm{pH} 4.0$ in aqueous medium and at ionic strength $0.1 \mathrm{~mol} \mathrm{dm}^{-3} \mathrm{NaClO}_{4}$.

$\left.-\mathrm{H}^{+}\right)^{+}$; the relative abundance of isotope peaks match the expected values, i.e., $\mathrm{m} / \mathrm{z} 407.3076, \mathrm{~m} / \mathrm{z} 409.3076$ and $\mathrm{m} / \mathrm{z} 411.3124$ (figure 5). ${ }^{19}$

The ${ }^{1} \mathrm{H}$ NMR spectrum of $\mathrm{L}^{1} \mathrm{H}$ exhibits only two doublets, centred at $\delta 7.5$ and $6.08 \mathrm{ppm}$, assigned to $\mathrm{C}_{5}$ and $\mathrm{C}_{6}$ protons, respectively. The amide protons are not detected in the spectrum and data suggest that the ligand exists in rapid equilibrium. If we look at the ${ }^{1} \mathrm{H}$ NMR of the platinum complex, the peak of the $\mathrm{C}_{5}$ and $\mathrm{C}_{6}$ proton is shifted significantly. This clearly indicates the coordination of the $\mathrm{L}^{1} \mathrm{H}$ with metal centre (figure 6). Thus the structures proposed here for product ion species, deduced from ESI-mass and NMR spectra are consistent with those derived from other experimental methods.

\subsection{Physical measurement}

All the spectral scanning and kinetic measurements were done in a Shimadzu UV 2450 spectrophotometer attached to a thermoelectric cell temperature controller (model TCC-240A with an accuracy of $\pm 0.1^{\circ} \mathrm{C}$ ). IR Spectra ( $\mathrm{KBr}$ disc, $4000-350 \mathrm{~cm}^{-1}$ ) were measured in Perkin-Elmer FTIR model RX1 Infrared spectrophotometer. ESI-mass spectra recorded using a micromass Q-Tof micro ${ }^{\mathrm{TM}}$ mass spectrometer in + ve ion mode. ${ }^{1} \mathrm{H}$ NMR spectrum was recorded using Bruker AVANCE III $400 \mathrm{MHz}$ spectrometer. The $\mathrm{pHs}$ of the solutions were adjusted by adding $\mathrm{NaOH} / \mathrm{HClO}_{4}$ and the measurements were carried out with the help of a Sartorius Digital $\mathrm{pH}$ meter (model PB11) with an accuracy of \pm 0.01 units. Doubly distilled water was used to prepare all the solution. All other chemicals used were of AR grade. The reactions were carried out at constant ionic strength $\left(0.10 \mathrm{~mol} \mathrm{dm}^{-3} \mathrm{NaClO}_{4}\right)$.

\subsection{Kinetic measurements}

The kinetics of substitution of coordinated water molecule was followed spectrophotometrically by following the change in absorption at suitable wavelengths as a function of time. The working wavelengths were determined by recording the spectra of the reaction mixture over the wavelength range between 200 and $500 \mathrm{~nm}$ and are given in figure 1. All kinetic experiments were performed under pseudo-first-order conditions. The reactions were initiated by mixing equal volume of complex and ligand solutions $(1.5 \mathrm{~mL})$ in the quartz cuvette. The absorption due to ligands was subtracted by using 1:1 (molar ratio) ligand:water mixture in the reference cell. The concentration of ligand solution was always large enough (at least a ten-fold excess) to provide pseudo-first-order conditions. A typical plot of $\ln \left(\mathrm{A}_{\infty}-\mathrm{A}_{\mathrm{t}}\right.$ ) (where $\mathrm{A}_{\mathrm{t}}$ and $\mathrm{A}_{\infty}$ are absorbances at time $(t)$ and after completion of reaction) against time (figure 7) is found to be nonlinear; it is curved at initial stage and subsequently of constant slope indicating that the reaction proceeds via two consecutive steps. From the limiting linear portion of $\ln \left(\mathrm{A}_{\infty}-\mathrm{A}_{\mathrm{t}}\right)$ versus time $(t)$ curve, $k_{2(o b s)}$ were obtained. The $k_{1(o b s)}$ values were obtained from the plots of $\ln \Delta$ versus time (t) where time $(\mathrm{t})$ is small (figure 8 ). Origin software was 


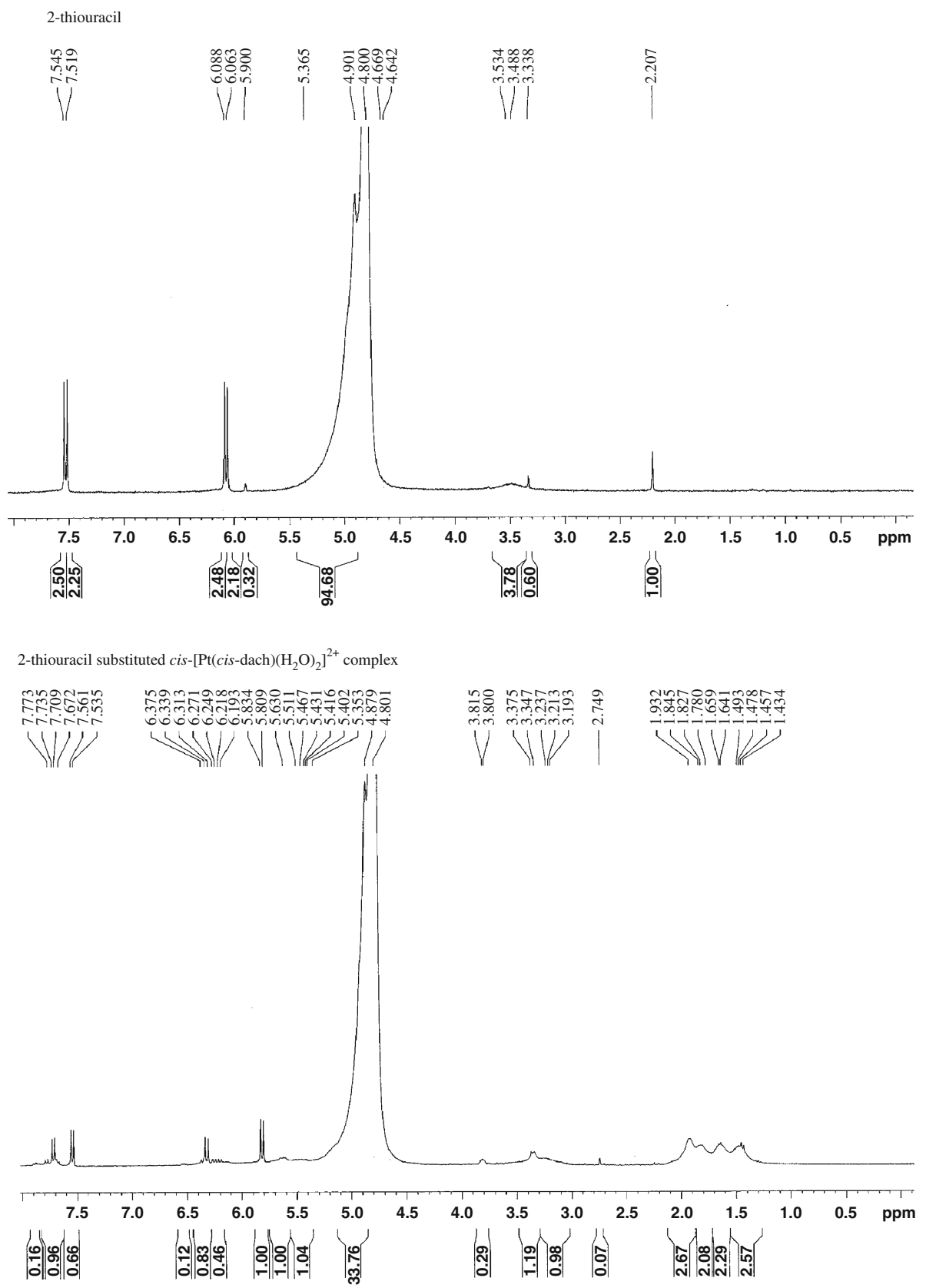

Figure 6. ${ }^{1} \mathrm{H}$ NMR spectra of 2-thiouracil and its substituted product.

used for computational works. Rate data, represented as an average of duplicate runs, are reproducible within $\pm 4 \%$.

\section{Results and discussion}

The $\mathrm{pK}_{\mathrm{a}}$ values of the ligands $\mathrm{L}^{1} \mathrm{H}, \mathrm{L}^{2} \mathrm{H}$ and $\mathrm{L}^{3} \mathrm{H}$ are 9.78 and $12.7,{ }^{20} 12.0^{21}$ and $8.76,{ }^{22}$ respectively, at $25^{\circ} \mathrm{C}$. So at $\mathrm{pH} 4.0$, ligands remain in the neutral form, which participate in the reaction. The $\mathrm{pK}_{1}$ and $\mathrm{pK}_{2}$ (6.25 and 7.80) for cis-(diaqua(cis-1,2diaminocyclohexane)platinum(II) has been evaluated by Irving-Rossotti titration technique. ${ }^{23}$ Therefore we can assume that at $\mathrm{pH} 4.0$ the reactant exists as the diaqua ion. The reactions followed two-step consecutive process; the first step is dependent on ligand concentration whereas the second is the independent of ligand concentration. In the first step one aqua ligand was replaced from cis- $\left[\mathrm{Pt}(\text { cis-dach })\left(\mathrm{OH}_{2}\right)_{2}\right]^{2+}$ by LH. The second is a slower step, where another aqua ligand is substituted. This is the ring closure step. The rate constant for such a process can be evaluated by assuming the following scheme

$$
\mathbf{A} \stackrel{\mathrm{k}_{1}}{\longrightarrow} \mathbf{B} \stackrel{\mathrm{k}_{2}}{\longrightarrow} \mathbf{C}
$$




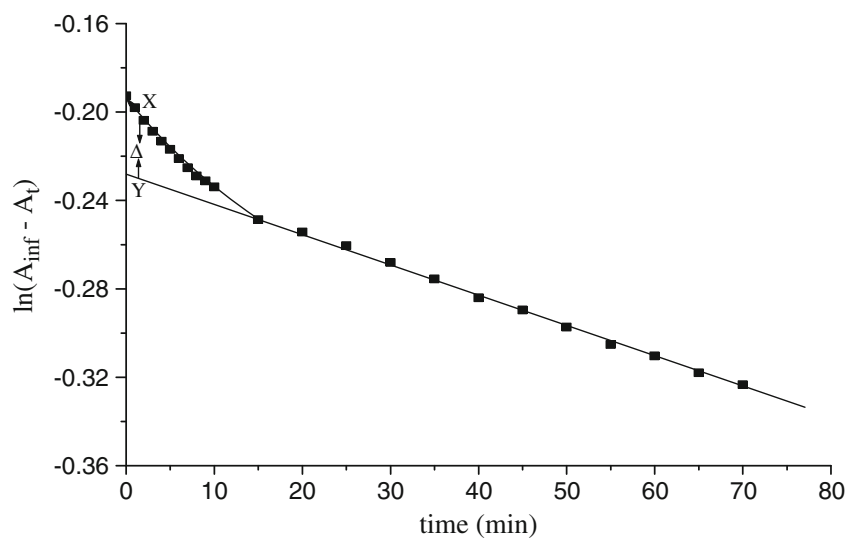

Figure 7. A typical kinetic plot of $\ln \left(\mathrm{A}_{\infty}-\mathrm{A}_{t}\right)$ versus time $(\mathrm{t})$. [complex (1)] $=2 \times 10^{-4} \mathrm{~mol} \mathrm{dm}-3 ;\left[\mathrm{L}^{2} \mathrm{H}\right]=$ $2 \times 10^{-3} \mathrm{~mol} \mathrm{dm}{ }^{-3} ; \mathrm{pH}=4.0 ; \mu=0.1 \mathrm{~mol} \mathrm{dm}^{-3} \mathrm{NaClO}_{4}$ and temperature $=35^{\circ} \mathrm{C}$.

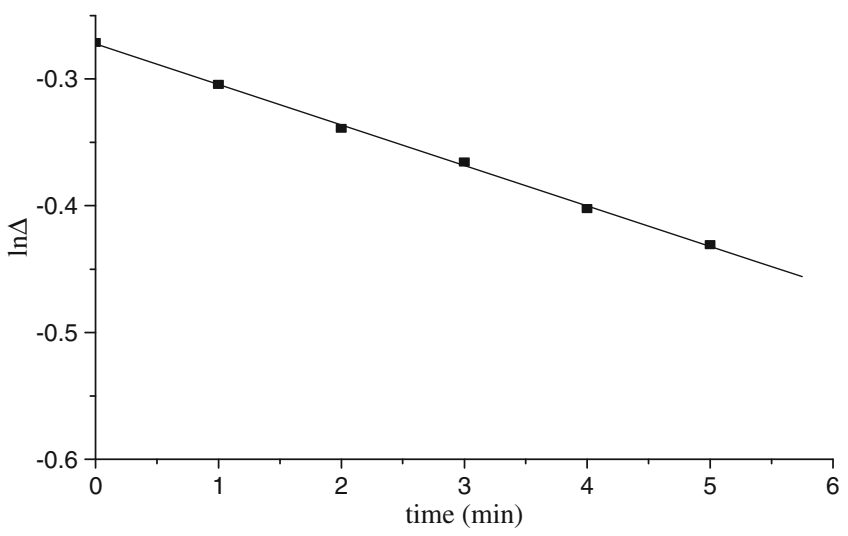

Figure 8. A typical kinetic plot of $\ln \Delta$ versus time (t). $[\operatorname{complex}(\mathbf{1})]=2.0 \times 10^{-4} \mathrm{~mol} \mathrm{dm}{ }^{-3} ;\left[\mathrm{L}^{2} \mathrm{H}\right]=2.0 \times$ $10^{-3} \mathrm{~mol} \mathrm{dm}{ }^{-3} ; \mathrm{pH}=4.0 ; \mu=0.1 \mathrm{~mol} \mathrm{dm}^{-3} \mathrm{NaClO}_{4}$ and temperature $=35^{\circ} \mathrm{C}$. where $\mathrm{A}$ is the diaqua species (1); B is the single substituted intermediate and $\mathrm{C}$ is the final product $[\mathrm{Pt}(\mathrm{cis}$ dach $)(\mathrm{L})]^{+}$. Formation of $\mathrm{C}$ from $\mathrm{B}$ is predominant after some time has elapsed.

\subsection{Calculation of $k_{1}$ for $A \rightarrow B$ step}

The rate constant $\mathrm{k}_{1(\mathrm{obs})}$ for the $\mathrm{A} \rightarrow \mathrm{B}$ step can be evaluated by the method of Wey and Hamm ${ }^{24}$ using the usual consecutive rate law. ${ }^{25} \mathrm{~A}$ similar procedure is applied for all ligands in the concentration range of 0.002-0.006 $\mathrm{mol} \mathrm{dm}^{-3}$ at constant complex (1) concentration of $0.0002 \mathrm{~mol} \mathrm{dm}^{-3}$ at $\mathrm{pH} 4.0$ and at 30, 35, 40,45 and $50^{\circ} \mathrm{C}$, respectively. The $\mathrm{k}_{1(\mathrm{obs})}$ values thus obtained are linearly dependent on the studied concentration range. The $\mathrm{k}_{1(\mathrm{obs})}$ values for different ligand concentrations at different temperatures are given in table 1 . The ligand concentration dependence of $\mathrm{k}_{1(\mathrm{obs})}$ values can be explained in terms of rapid formation of an outer sphere association complex between the reactant complex (1) and the sulphur end of neutral form of $\mathrm{L}^{1} \mathrm{H}$ in the $\mathrm{A} \longrightarrow \mathrm{B}$ stage. The rate increases with increase in ligand concentration and reaches a limiting value (figure 9), which is probable due to the completion of the outer sphere association complex formation. Since the metal ion reacts with immediate environment, further change in ligand concentration beyond the saturation point will not affect the reaction rate and a gradual approach towards limiting rate is observed. At this stage, the interchange of the ligands from outer sphere

Table 1. $10^{3} \mathrm{k}_{1 \text { (obs) }}\left(\mathrm{s}^{-1}\right)$ values for ligand concentrations at different temperatures. $[$ complex $(1)]=2.00 \times 10^{-4} \mathrm{~mol} \mathrm{dm}{ }^{-3}, \mathrm{pH}=4.0$, ionic strength $=0.1 \mathrm{~mol} \mathrm{dm}^{-3}$ $\mathrm{NaClO}_{4}$.

\begin{tabular}{lcccccc}
\hline & & \multicolumn{5}{c}{$10^{3} \times[$ Ligand $]\left(\mathrm{mol} \mathrm{dm}^{-3}\right)$} \\
\cline { 3 - 7 } Ligand & $\begin{array}{c}\text { Temperature } \\
\left( \pm 0.1^{\circ} \mathrm{C}\right)\end{array}$ & 2.00 & 3.00 & 4.00 & 5.00 & 6.00 \\
\hline $\mathrm{L}^{1} \mathrm{H}$ & 30 & 2.60 & 3.33 & 3.98 & 4.43 & 4.76 \\
& 35 & 3.74 & 4.70 & 5.37 & 5.74 & 6.18 \\
& 40 & 4.89 & 6.04 & 6.69 & 7.18 & 7.61 \\
& 45 & 5.72 & 6.89 & 7.68 & 8.15 & 8.60 \\
& 50 & 6.18 & 7.35 & 8.22 & 8.72 & 9.18 \\
$\mathrm{~L}^{2} \mathrm{H}$ & 30 & 0.38 & 0.49 & 0.59 & 0.69 & 0.76 \\
& 35 & 0.53 & 0.71 & 0.83 & 0.97 & 1.03 \\
& 40 & 0.78 & 0.97 & 1.18 & 1.36 & 1.49 \\
& 45 & 1.16 & 1.46 & 1.70 & 1.89 & 2.11 \\
& 50 & 1.75 & 2.16 & 2.47 & 2.67 & 2.85 \\
$\mathrm{~L}^{3} \mathrm{H}$ & 30 & 0.33 & 0.43 & 0.51 & 0.58 & 0.65 \\
& 35 & 0.47 & 0.60 & 0.71 & 0.80 & 0.88 \\
& 40 & 0.66 & 0.84 & 0.97 & 1.11 & 1.21 \\
& 45 & 0.93 & 1.18 & 1.36 & 1.50 & 1.67 \\
& 50 & 1.49 & 1.83 & 2.08 & 2.27 & 2.43 \\
\hline
\end{tabular}


to the inner sphere occurs. The following scheme can

be proposed;

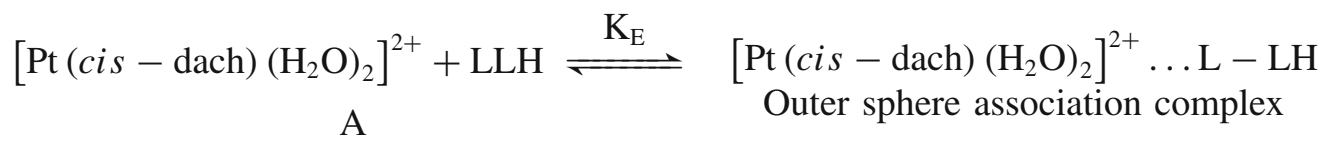

$$
\begin{aligned}
& {\left[\mathrm{Pt}(\text { cis }- \text { dach })\left(\mathrm{H}_{2} \mathrm{O}\right)_{2}\right]^{2+} \ldots \mathrm{L}-\mathrm{LH} \underset{\text { anation }}{\stackrel{\mathrm{k}_{1}}{\longrightarrow}} \stackrel{\left[\mathrm{Pt}(\text { cis }- \text { dach })\left(\mathrm{H}_{2} \mathrm{O}\right)(\mathrm{L}-\mathrm{LH})\right]^{2+}+\mathrm{H}_{2} \mathrm{O}}{\mathrm{B}}}
\end{aligned}
$$

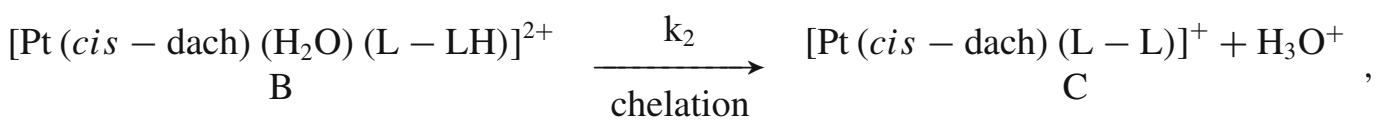

where $\mathrm{L}-\mathrm{LH}$ indicate bidentate form of $\mathrm{L}^{1} \mathrm{H}, \mathrm{L}^{2} \mathrm{H}$ and $\mathrm{L}^{3} \mathrm{H}$. Based on the above equations a rate expression (7) can be derived for the $\mathrm{A} \rightarrow \mathrm{B}$ step:

$$
\begin{aligned}
\mathrm{dB} / \mathrm{dt}= & \mathrm{k}_{1} \mathrm{~K}_{\mathrm{E}}\left[\mathrm{Pt}(\text { cis }- \text { dach })\left(\mathrm{H}_{2} \mathrm{O}\right)_{2}^{2+}\right]_{\text {total }}[\mathrm{LH}] / 1 \\
& +\mathrm{K}_{\mathrm{E}}[\mathrm{LH}]
\end{aligned}
$$

or,

$$
\mathrm{dB} / \mathrm{dt}=\mathrm{k}_{1(\mathrm{obs})}\left[\mathrm{Pt}(\text { cis }- \text { dach })\left(\mathrm{H}_{2} \mathrm{O}\right)_{2}^{2+}\right]_{\text {total }},
$$

where $\left[\mathrm{Pt}(\text { cis-dach })\left(\mathrm{H}_{2} \mathrm{O}\right)_{2}^{2+}\right]_{\text {total }}$ is the total concentration of the complex, $[\mathrm{LH}]$ is the concentration of the bio-active ligands. Hence we can write;

$$
\mathrm{k}_{1(\mathrm{obs})}=\mathrm{k}_{1} \mathrm{~K}_{\mathrm{E}}[\mathrm{LH}] / 1+\mathrm{K}_{\mathrm{E}}[\mathrm{LH}]
$$

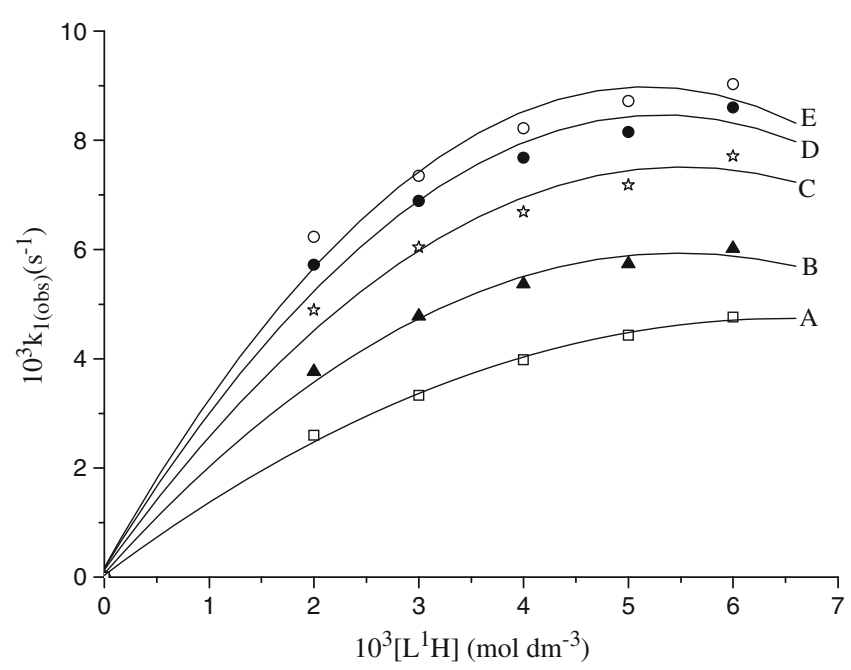

Figure 9. Plots of $10^{3} \mathrm{k}_{1(\mathrm{obs})}\left(\mathrm{s}^{-1}\right)$ versus $\left[\mathrm{L}^{1} \mathrm{H}\right]$ at different temperatures; $\mathrm{A}=30^{\circ} \mathrm{C}, \mathrm{B}=35^{\circ} \mathrm{C}, \mathrm{C}=40^{\circ} \mathrm{C}, \mathrm{D}=45^{\circ} \mathrm{C}$ and $\mathrm{E}=50^{\circ} \mathrm{C} ; \mathrm{pH} 4.0$ and ionic strength $=0.10 \mathrm{~mol} \mathrm{dm}^{-3}$ $\mathrm{NaClO}_{4}$. where $\mathrm{k}_{1}$ is the rate constant for conversion of outer sphere complex to inner sphere complex and $\mathrm{K}_{\mathrm{E}}$ is the outer sphere association equilibrium constant. Equation (6) can be rearranged:

$$
1 / \mathrm{k}_{1(\mathrm{obs})}=1 / \mathrm{k}_{1}+1 / \mathrm{k}_{1} \mathrm{~K}_{\mathrm{E}}[\mathrm{LH}] .
$$

A plot of $1 / \mathrm{k}_{1 \text { (obs) }}$ versus $1 /[\mathrm{LH}]$ should be linear with an intercept of $1 / \mathrm{k}_{1}$ and slope $1 / \mathrm{k}_{1} \mathrm{~K}_{\mathrm{E}}$. This was found to be so, at all temperature studied (figure 10). The $\mathrm{k}_{1}$ and $\mathrm{K}_{\mathrm{E}}$ values obtained from intercept and from slope to intercept ratios are included in table 2 .

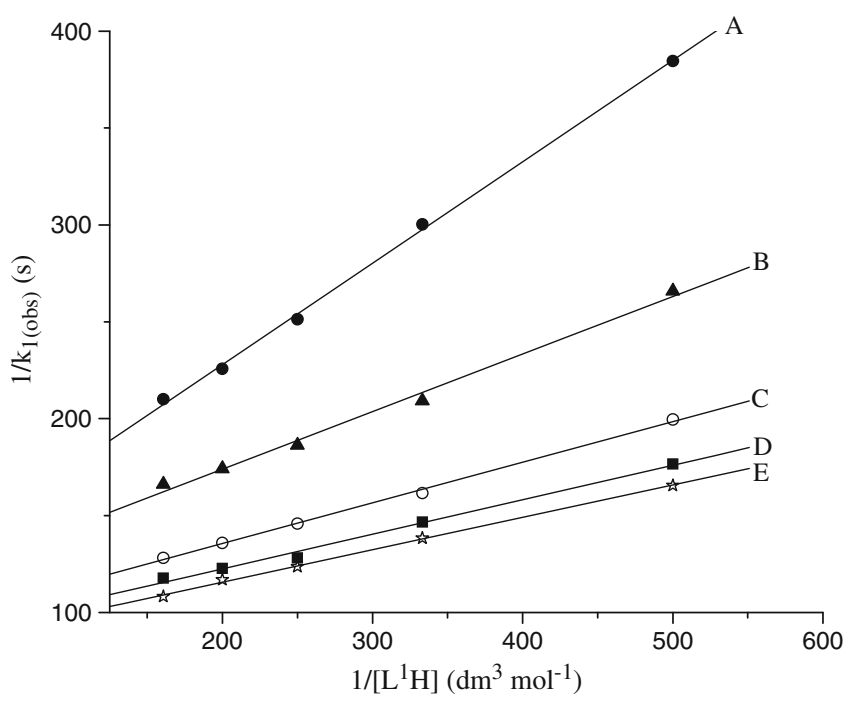

Figure 10. Plots of $1 / \mathrm{k}_{1(\mathrm{obs})}$ ( $\left.\mathrm{s}\right)$ versus $1 /\left[\mathrm{L}^{1} \mathrm{H}\right]$ at different temperatures; $\mathrm{A}=30^{\circ} \mathrm{C}, \mathrm{B}=35^{\circ} \mathrm{C}, \mathrm{C}=40^{\circ} \mathrm{C}, \mathrm{D}=$ $45^{\circ} \mathrm{C}$ and $\mathrm{E}=50^{\circ} \mathrm{C} ; \mathrm{pH} 4.0$ and ionic strength $=0.10 \mathrm{~mol}$ $\mathrm{dm}^{-3} \mathrm{NaClO}_{4}$. 
Table 2. $10^{5} \mathrm{k}_{2(\mathrm{obs})}\left(\mathrm{s}^{-1}\right)$ values for ligand concentrations at different temperatures. [complex $(1)]=2.00 \times 10^{-4} \mathrm{~mol} \mathrm{dm}{ }^{-3}, \mathrm{pH}=4.0$, ionic strength $=0.1 \mathrm{~mol} \mathrm{dm}^{-3}$ $\mathrm{NaClO}_{4}$.

\begin{tabular}{lcccccc}
\hline & $\begin{array}{c}\text { Temperature } \\
\text { Ligand }\end{array}$ & \multicolumn{5}{c}{$10^{3} \times[$ Ligand $]\left(\mathrm{mol} \mathrm{dm}^{-3}\right)$} \\
\cline { 3 - 7 } $\mathrm{L}^{1} \mathrm{H}$ & $\left.30.1^{\circ} \mathrm{C}\right)$ & 2.00 & 3.00 & 4.00 & 5.00 & 6.00 \\
& 30 & 3.61 & 3.64 & 3.63 & 3.66 & 3.64 \\
& 35 & 4.41 & 4.40 & 4.40 & 4.41 & 4.42 \\
& 40 & 5.09 & 5.11 & 5.10 & 5.10 & 5.12 \\
& 45 & 6.13 & 6.15 & 6.13 & 6.10 & 6.16 \\
$\mathrm{~L}^{2} \mathrm{H}$ & 50 & 7.20 & 7.20 & 7.21 & 7.22 & 7.19 \\
& 30 & 1.88 & 1.86 & 1.87 & 1.88 & 1.89 \\
& 35 & 2.34 & 2.35 & 2.35 & 2.37 & 2.36 \\
& 40 & 3.22 & 3.24 & 3.25 & 3.26 & 3.24 \\
& 45 & 4.49 & 4.47 & 4.48 & 4.49 & 4.45 \\
$\mathrm{~L}^{3} \mathrm{H}$ & 50 & 5.55 & 5.53 & 5.52 & 5.50 & 5.51 \\
& 30 & 1.70 & 1.73 & 1.72 & 1.72 & 1.74 \\
& 35 & 2.32 & 2.33 & 2.30 & 2.35 & 2.33 \\
& 40 & 3.16 & 3.17 & 3.15 & 3.14 & 3.18 \\
& 45 & 4.23 & 4.28 & 4.25 & 4.25 & 4.24 \\
& 50 & 5.32 & 5.33 & 5.34 & 5.31 & 5.34 \\
\hline
\end{tabular}

\subsection{Calculation of $k_{2}$ for the $B \rightarrow C$ step}

The $\mathrm{B} \rightarrow \mathrm{C}$ step is the ring closure step in which the second donor site of LH binds the metal centre. Due to the steric hindrance, this chelation step is slower and independent of ligand concentration variation. At each temperature, the $\mathrm{k}_{2}$ values were calculated from the limiting linear portion (where time ( $\mathrm{t}$ ) is large) of the $\ln \left(\mathrm{A}_{\infty}-\mathrm{A}_{\mathrm{t}}\right)$ versus time ( $\mathrm{t}$ ) curves (figure 7 ) and are given in tables 2 and 3. Unlike $\mathrm{k}_{1}, \mathrm{k}_{2}$ was found to be independent of ligand concentration at each of the temperature studied.

\subsection{Effect of $p H$ on reaction rate}

The reaction was studied at five different $\mathrm{pH}$ values. At a fixed $2.00 \times 10^{-4} \mathrm{~mol} \mathrm{dm}^{-3}$ [complex (1)], $4.00 \times$ $10^{-3} \mathrm{~mol} \mathrm{dm}^{-3}[\mathrm{LH}]$ and $0.10 \mathrm{~mol} \mathrm{dm}^{-3} \mathrm{NaClO}_{4}$ ionic

Table 3. $10^{3} \mathrm{k}_{1}, 10^{5} \mathrm{k}_{2}$ and $\mathrm{K}_{\mathrm{E}}$ values for different ligands at different temperatures, [complex (1)] $=2.00 \times 10^{-4} \mathrm{~mol} \mathrm{dm}^{-3}, \mathrm{pH}=4.0$, ionic strength $=0.1 \mathrm{~mol} \mathrm{dm}^{-3} \mathrm{NaClO}_{4}$.

\begin{tabular}{lcrcc}
\hline Ligand & $\begin{array}{c}\text { Temperature } \\
\left( \pm 0.1^{\circ} \mathrm{C}\right)\end{array}$ & $10^{3} \mathrm{k}_{1}\left(\mathrm{~s}^{-1}\right)$ & $10^{5} \mathrm{k}_{2}\left(\mathrm{~s}^{-1}\right)$ & $\mathrm{K}_{\mathrm{E}}\left(\mathrm{dm}^{-3} \mathrm{~mol}^{-1}\right)$ \\
\hline $\mathrm{L}^{1} \mathrm{H}$ & 30 & 8.11 & 3.64 & 235 \\
& 35 & 9.05 & 4.41 & 355 \\
& 40 & 10.42 & 5.10 & 447 \\
& 45 & 11.39 & 6.13 & 508 \\
$\mathrm{~L}^{2} \mathrm{H}$ & 50 & 12.01 & 7.20 & 531 \\
& 30 & 1.47 & 1.88 & 171 \\
& 35 & 2.02 & 2.35 & 179 \\
& 40 & 2.70 & 3.24 & 195 \\
$\mathrm{~L}^{3} \mathrm{H}$ & 45 & 3.38 & 4.48 & 258 \\
& 50 & 4.15 & 5.52 & 364 \\
& 30 & 1.20 & 1.72 & 188 \\
& 45 & 1.53 & 2.33 & 214 \\
& 45 & 2.01 & 3.16 & 249 \\
& 50 & 2.64 & 4.25 & 277 \\
& & 3.51 & 5.33 & 368 \\
\hline
\end{tabular}


Table 4. $10^{3} \mathrm{k}_{1(\mathrm{obs})}$ and $10^{5} \mathrm{k}_{2(\mathrm{obs})}$ values for different ligands at different $\mathrm{pH},[\operatorname{complex}(\mathbf{1})]=2.00 \times 10^{-4} \mathrm{~mol} \mathrm{dm}^{-3}$, $[\mathrm{LH}]=4.00 \times 10^{-3} \mathrm{~mol} \mathrm{dm}{ }^{-3}$, ionic strength $=0.1 \mathrm{~mol}$ $\mathrm{dm}^{-3} \mathrm{NaClO}_{4}$.

\begin{tabular}{lccc}
\hline Ligand & $\mathrm{pH}( \pm 0.01)$ & $10^{3} \mathrm{k}_{1}\left(\mathrm{~s}^{-1}\right)$ & $10^{5} \mathrm{k}_{2}\left(\mathrm{~s}^{-1}\right)$ \\
\hline $\mathrm{L}^{1} \mathrm{H}$ & 3.0 & 6.65 & 3.17 \\
& 3.5 & 6.66 & 4.25 \\
& 4.0 & 6.69 & 5.10 \\
& 4.5 & 6.69 & 6.86 \\
$\mathrm{~L}^{2} \mathrm{H}$ & 5.0 & 6.71 & 8.94 \\
& 3.0 & 1.17 & 1.69 \\
& 3.5 & 1.18 & 2.40 \\
& 4.0 & 1.18 & 3.24 \\
$\mathrm{~L}^{3} \mathrm{H}$ & 4.5 & 1.19 & 4.51 \\
& 5.0 & 1.19 & 6.01 \\
& 3.0 & 0.95 & 2.12 \\
& 3.5 & 0.96 & 2.73 \\
& 4.0 & 0.97 & 3.16 \\
& 4.5 & 0.97 & 4.06 \\
& 5.0 & 0.98 & 5.13 \\
\hline
\end{tabular}

strength, the $10^{3} \mathrm{k}_{1(\mathrm{obs})}$ and $10^{5} \mathrm{k}_{2(\mathrm{obs})}$ values are given in table 4 at $40^{\circ} \mathrm{C}$. The $\mathrm{k}_{2 \text { (obs) }}$ values were only found to increase with the increase in $\mathrm{pH}$ in the studied $\mathrm{pH}$ range. The enhancement in rate may be explained by the acid dissociation equilibria of the ligands and the complex. Within our studied $\mathrm{pH}$ range the ligands remain unchanged, so the effects of $\mathrm{pH}$ on rate are therefore due to the change in reactive forms of the reacting complex. The complex changes its form, from aqua to hydroxoaqua. The hydroxo species is more reactive due to the well-known labilising effect of the $-\mathrm{OH}$ group via its $\pi$-bonding ability and strong electromeric effect.

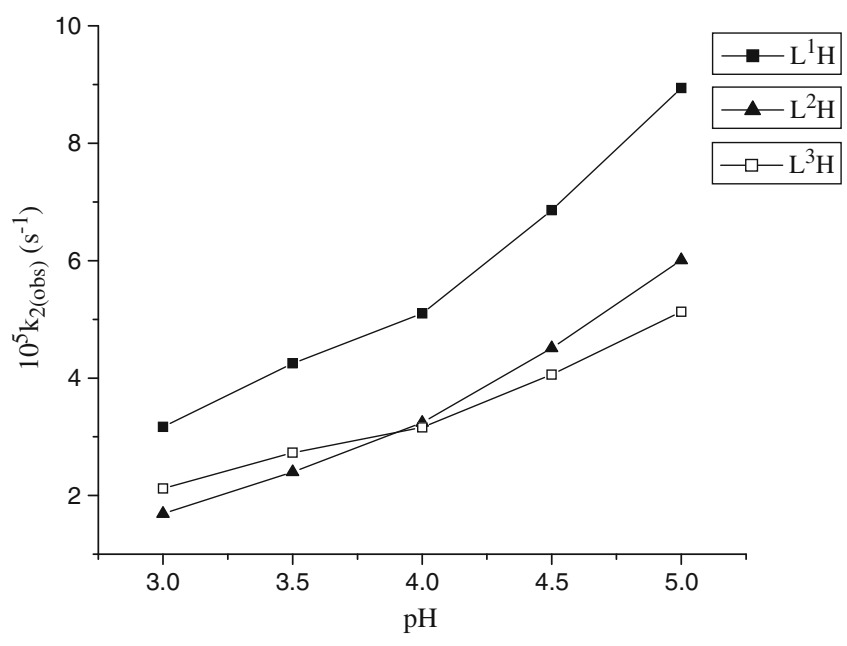

Figure 11. Plots of $\mathrm{pH}$ versus $10^{5} \mathrm{k}_{2(\mathrm{obs})}$ for the three ligands.
The $\mathrm{pH}$ dependence of $\mathrm{k}_{2 \text { (obs) }}$ can also be readily interpreted in terms of the changes with $\mathrm{pH}$ in fractional populations of species involved in the respective reactions. ${ }^{26}$ From the plot of $\mathrm{pH}$ versus $10^{5} \mathrm{k}_{2 \text { (obs) }}$ (figure 11) for three ligands shows that after $\mathrm{pH} 4.0$ all the ligands have greater sensitivity with $\mathrm{pH}$ which is consistent with the $\mathrm{pK}_{\mathrm{a}}$ value of the mono substituted complex. Notwithstanding in the present kinetic runs, the substitution reactions were followed at a constant $\mathrm{pH}$ of 4.0 to avoid complication caused by adding an additional parameter of $\left[\mathrm{H}^{+}\right]$to the rate equation.

\subsection{Effect of temperature on reaction rate}

The reaction was studied at five different temperatures for different ligand concentrations and the anation rate constants for both $\mathrm{A} \rightarrow \mathrm{B}\left(\mathrm{k}_{1}\right)$ and $\mathrm{B} \rightarrow \mathrm{C}\left(\mathrm{k}_{2}\right)$ steps are given in table 3 . The activation parameters calculated from Eyring plots (figures 12 and 13) are given in

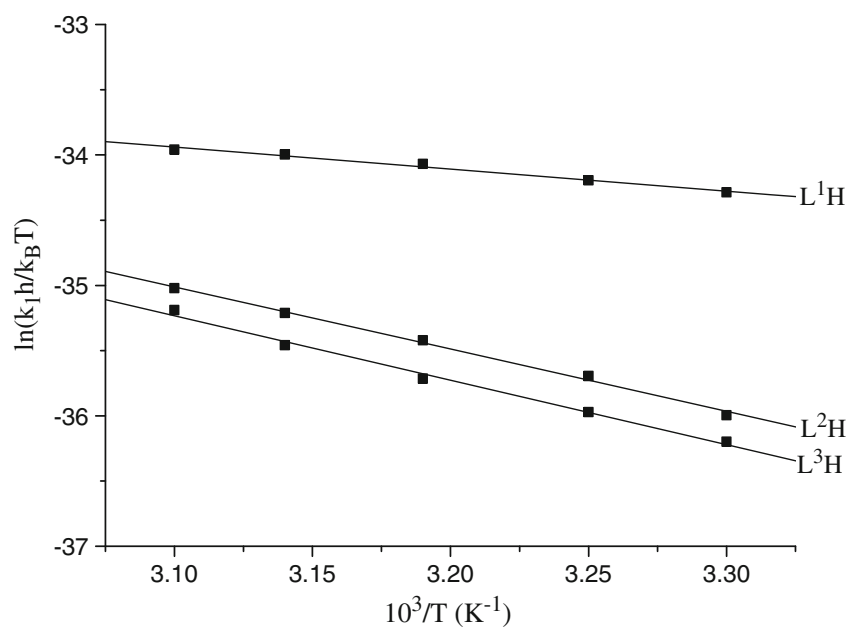

Figure 12. Eyring plots of $\mathrm{L}_{1} \mathrm{H}, \mathrm{L}_{2} \mathrm{H}$ and $\mathrm{L}_{3} \mathrm{H}$ for $\mathrm{k}_{1}$.

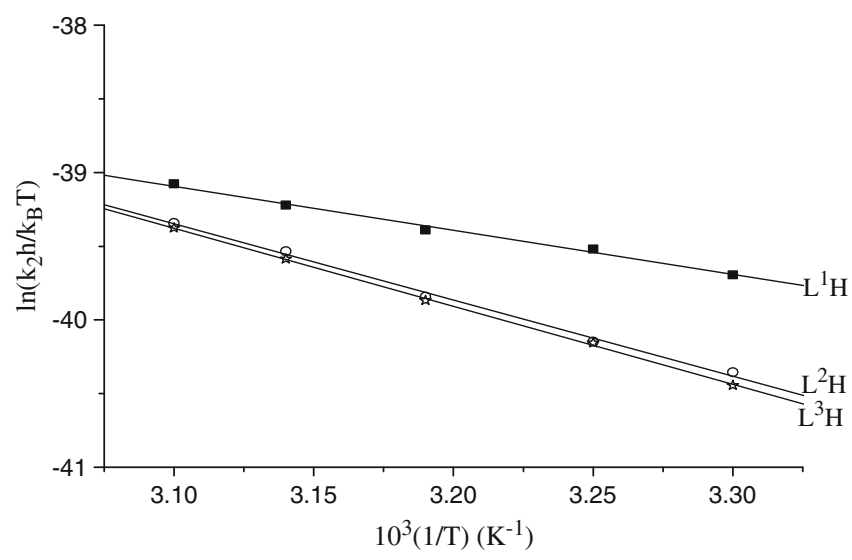

Figure 13. Eyring plots of $\mathrm{L}_{1} \mathrm{H}, \mathrm{L}_{2} \mathrm{H}$ and $\mathrm{L}_{3} \mathrm{H}$ for $\mathrm{k}_{2}$. 
Table 5. Activation parameters for analogous systems.

\begin{tabular}{lccccc}
\hline Systems & $\Delta \mathrm{H}_{1}^{\neq}\left(\mathrm{kJmol}^{-1}\right)$ & $\Delta \mathrm{S}_{1}^{\neq}\left(\mathrm{JK}^{-1} \mathrm{~mol}^{-1}\right)$ & $\Delta \mathrm{H}_{2}^{\neq}\left(\mathrm{kJmol}^{-1}\right)$ & $\Delta \mathrm{S}_{2}^{\neq}\left(\mathrm{JK}^{-1} \mathrm{~mol}^{-1}\right)$ & Refs. \\
\hline Cis-[Pt $($ cis-dach $\left.)\left(\mathrm{H}_{2} \mathrm{O}\right)_{2}\right]^{2+}$ & & & & & \\
/Glutathione & $32.9 \pm 1.3$ & $-187.2 \pm 4.2$ & $30.5 \pm 0.1$ & $-223.1 \pm 0.3$ & {$[27]$} \\
$/$ Et 2 DTC & $66.8 \pm 3.7$ & $-81 \pm 12$ & $95.1 \pm 2.8$ & $-34.4 \pm 9.1$ & {$[28]$} \\
$/$ DL-Penicillamine & $36.1 \pm 4.1$ & $-175 \pm 12$ & $44.4 \pm 1.1$ & $-189 \pm 3$ & {$[25]$} \\
$/ \mathrm{L}^{1} \mathrm{H}$ & $14.1 \pm 1.0$ & $-239 \pm 3$ & $24.9 \pm 1.2$ & $-248 \pm 4$ & {$[* *]$} \\
$/ \mathrm{L}^{2} \mathrm{H}$ & $39.7 \pm 1.5$ & $-168 \pm 5$ & $43.0 \pm 1.5$ & $-194 \pm 5$ & {$[* *]$} \\
$/ \mathrm{L}^{3} \mathrm{H}$ & $41.1 \pm 2.0$ & $-166 \pm 6$ & $44.1 \pm 0.7$ & $-191 \pm 2.1$ & {$[* *]$} \\
\hline
\end{tabular}

***This work

table 5 and compared with those for analogous systems involving the substitution in square planar platinum(II) complexes.

\section{Mechanism and conclusion}

All the ligands exist as neutral molecules at experimental $\mathrm{pH}$ 4.0. Job's method of continuous variation indicate 1:1 molar ratio and the IR spectra of the solid products suggest that the ligands behaved as bidentate ligand. Finally, ${ }^{1} \mathrm{H}$ NMR and ESI-mass spectra provide a qualitative picture of the composition i.e., the ligational sites of the nucleophiles. Thus, the mechanism of substitution of aqua ligands in cis-diaqua(cis-1,2diaminocyclohexane)platinum(II) ion can be explained in terms of rapid outer sphere association complex formation, followed by two consecutive steps; the first is dependent on ligand concentration and second is the chelation i.e., ring closure step, which is slower than the first step and independent of ligand concentration (figure 14).

The rate constant ' $\mathrm{k}_{1}$ ' for the ligands 2-thiouracil $(\mathrm{S}, \mathrm{N}), 1,2$-cyclohexanedionedioxime $(\mathrm{N}, \mathrm{N})$ and acetylacetone $(\mathrm{O}, \mathrm{O})$ of different donor sets, can be rearranged as

$$
\begin{aligned}
& 2-\text { thiouracil }>1,2-\text { cyclohexanedionedioxime } \\
& >\text { acetylacetone. }
\end{aligned}
$$

The sulphur end of 2-thiouracil is a soft donor centre and has large affinity for the soft Pt centre. The sulphur containing ligands have higher reactivity than ligands containing no sulphur atom. This is due to ability of sulphur atom to function both as $\sigma$-donor and as $\pi$-acceptor. Aside this, Pt(II) is soft acid and soft-soft interaction initiates the preference of $\mathrm{Pt}(\mathrm{II})$ to sulphur ligands. The cyclization process occurs with deprotonation, a phenomenon, which is dependent on the $\mathrm{pH}$ and on the nature of the metal ion. At $\mathrm{pH} 4.0$, deprotonation is difficult to occur resulting the reaction becomes<smiles>CCO[P]1(O)NC2CCCCC2N1</smiles>

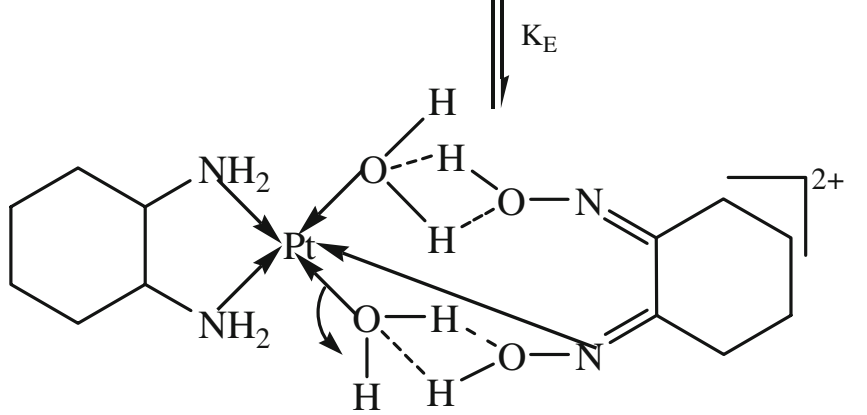

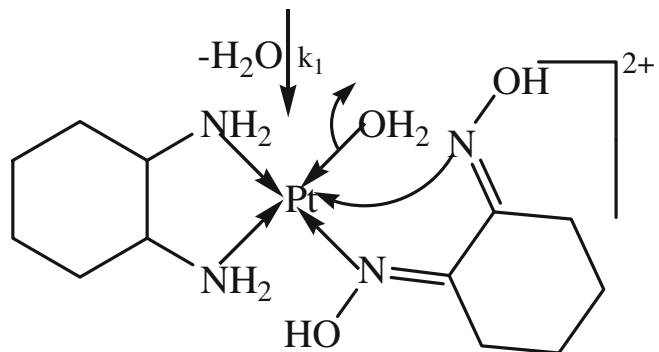<smiles>[O-][N+]1=C2[C+]CCCC2=[N+](O)C12NC1CCCCC1N2</smiles>

Figure 14. Plausible mechanism for the substitution of the aqua ligand from cis- $\left[\mathrm{Pt}(\text { cis-dach })\left(\mathrm{H}_{2} \mathrm{O}\right)_{2}\right]^{2+}$ by $\mathrm{L}^{2} \mathrm{H}$.

slower. With 1,2-cyclohexanedionedioxime, the presence of polar side chain probably helps deprotonation by lowering the energy barrier through solvation. Moreover, owing to better solvation of transition state caused 
by the presence of hydrophilic site in case of 1,2cyclohexanedionedioxime, shows higher rate than that of acetylacetone. Therefore Pt(II) has greater affinity for nitrogen centre than that of oxygen.

The trend in the reactivity of the ligands can also be seen in the activation enthalpies for the reactions involving the complex (1). The higher the nucleophilicity of the ligand, the smaller the activation enthalpy because of stabilization of the transition state.

The enthalpies of activation $\left(\Delta \mathrm{H}_{1}^{\neq}\right.$and $\left.\Delta \mathrm{H}_{2}^{\neq}\right)$values and negative values of entropies of activation $\left(\Delta S_{1}^{\neq}\right.$ and $\Delta \mathrm{S}_{2}^{\neq}$) imply a good degree of ligand participation in the transition state (table 3 ). The positive enthalpy change for breaking the $\mathrm{M}-\mathrm{OH}_{2}$ bond is partially compensated by the formation of $\mathrm{M}-\mathrm{L}$ bond in the transition state. The participation of $\mathrm{LH}$ in the transition state results in a more compact state and a negative $\Delta S^{\neq}$value is obtained. Further $\Delta S_{2}^{\neq}$is more negative than $\Delta \mathrm{S}_{1}^{\neq}$, which suggest that compactness has already been achieved in B and the transformation of B to C is only the replacement of another aqua ligand through chelation.

\section{Acknowledgements}

Authors thank the infrastructural facilities provided by the University of Burdwan, Burdwan, West Bengal, India.

\section{References}

1. Go R S and Adjei A A 1999 J. Clin. Oncol. 17409

2. Jamieson E R and Lippard S J 1999 Chem. Rev. 992467

3. Pérez R P 1998 Eur. J. Cancer 341535

4. Greene M H 1992 J. Natl. Cancer Inst. 84306
5. Wheate N J, Walker S, Craig G E and Oun R 2010 Dalton Trans. 398113

6. Kelland L R 2007 Nat. Rev. Cancer 7573

7. Wong E and Giandomenico C M 1999 Chem. Rev. 99 2451

8. Boudny V, Vrana O, Gaucheron F, Kleinwachter V, Leng M and Brabec V 1991 Nucleic Acids Res. 20267

9. Jung Y and Lippard S J, 2007 Chem. Rev. 1071387

10. Wang D and Lippard S J 2005 Nat. Rev. Drug Discov. 4307

11. Reedijk J 1999 Chem. Rev. 992499

12. Jamieson E R and Lippard S J 1999 Chem. Rev. 992467

13. Bugarcic Z D, Rosic J, Petrovic B, Summa N, Puchta R and Eldik R V 2007 J. Biol. Inorg. Chem. 121141

14. Khokhar A R, Krakoff I H, Hacker M P and McCormack J J 1985 Inorg. Chim. Acta 10863

15. Masoud M S, Ibrahim A A, Khalil E A and El-Marghany A 2007 Spectrochim. Acta Part A 67662

16. Arpalahti J and Lehikoinen P 1989 Inorg. Chim. Acta 159115

17. Yamanari K, Okusako K, Kushi Y and Kaizaki S 1992 J. Chem. Soc. Dalton Trans. 1621

18. Behke G T and Nakamoto K 1968 Inorg. Chem. 7330

19. Miao R, Yang G, Miao Y, Mei Y, Hong J, Zhao C and Zhu L 2005 Rapid Commun. Mass Spectrosc. 191031

20. Wen D, Zhu X, Zhao F, Huang L and Zeng B 2006 Solid State Electrochem. 1069

21. Sillen L G and Martell A E 1964 Stability constants of metal ion complexes, Special Publication No. 17. London: The Chemical Society

22. Sekine T and Hasegawa Y 1977 Solvent extraction chemistry. New York: Marcel Dekker

23. Irving H M and Rossotti H S 1954 J. Chem. Soc. 2904

24. Weyh J A and Hamm R E 1969 Inorg. Chem. 82298

25. Karmakar P, Bera B K, Barik K L, Mukhopadhyay S K and Ghosh A K 2010 J. Coord. Chem. 632158

26. Karmakar P, Mallick S, Mondal S, Bera B K, Mandal A, Mukhopadhyay S K and Ghosh A K 2011 Int. J. Chem. Kinet. $\mathbf{4 3} 219$

27. Sinha R, Choudhury A K and De G S 2003 Indian J. Chem. 42A 473

28. Mukhopadhyay S K 2008 Transition Met. Chem. 33739 